\section{Intestinal and appendiceal paracoccidioidomycosis}

Paracoccidioidomicose intestinal e apendicular

\section{Dear. Editor,}

A male, 20-year-old patient with hematochezia and enterorrhagia associated with weight loss. Colonoscopy demonstrated nonspecific rectitis, and histopathological analysis was compatible with Crohn's disease. The treatment was initiated and remission was observed.

After five months, the medication was interrupted without medical advice, and recurrence of the same initial symptoms was observed after one month, in addition to papular lesions, some of them pustular, scattered throughout the body and scalp. After five days of immunosuppressive therapy, progression of the papular lesions, onset of intensely painful, hemorrhagic lesions in the oral mucosa, and painful lymph nodes enlargement in cervical chains were observed. Then, the patient was transferred to the authors' institution where the assessment by the Unit of Dermatology raised the suspicion of paracoccidioidomycosis (PCM), confirmed by oral lesions smear and silver staining demonstrating the typical pinwheel cells. Rectosigmoidoscopy demonstrated granulomatous proctosigmoiditis and biopsy confirmed the diagnosis. Abdominal computed tomography (CT) identified ileocecal mass, appendiceal thickening with parietal contrast enhancement, adjacent peritoneal fat infiltration, mesenteric and retroperitoneal lymph nodes enlargement, besides parietal thickening of the rectum with pararectal gaseous foci at right, caused by fistulas, and perirectal fat blurring (Figure 1).

He was treated with amphotericin B which, after four days, resulted in improvement of the dermatological and painful condition. The tomographic follow-up revealed involution of the ileocecal, appendicular and rectal involvement.

The Brazilian radiological literature has recently highlighted the relevance of imaging methods in the diagnosis of the digestive system diseases ${ }^{(1-12)}$.
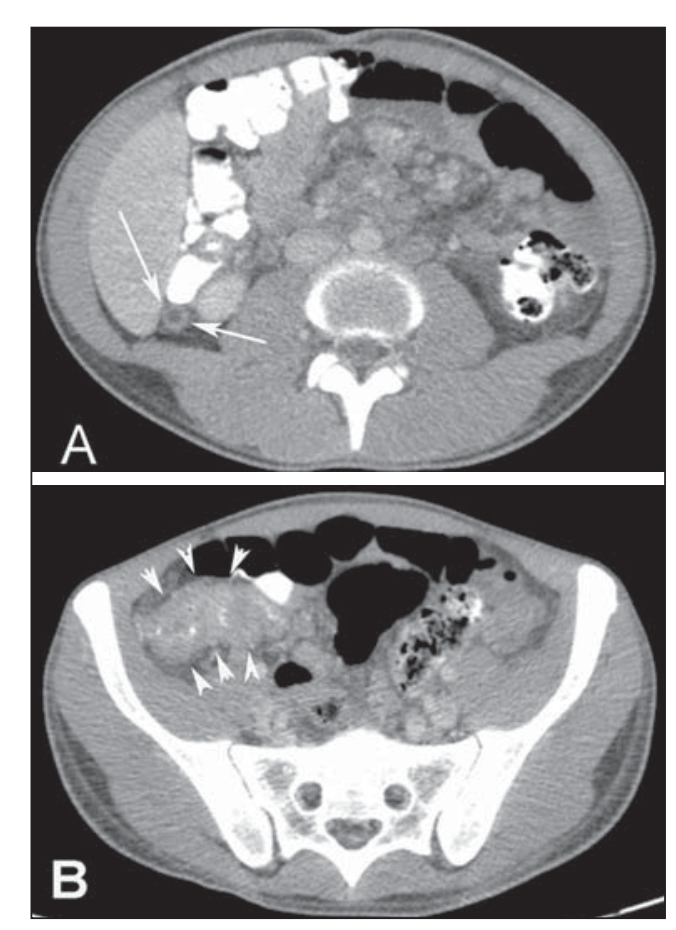

PCM is a systemic mycosis that is endemic in Latin American countries, caused by the thermo-dimorphic fungus Paracoccidioides brasiliensis ${ }^{(13)}$. Although all the digestive tract segments, from the mouth to the anus, may be affected by the $P$. brasiliensis, the lesions are more frequently found in regions which are rich in lymphoid tissue ${ }^{(14)}$, such as the terminal ileum, appendix and the right hemicolon ${ }^{(15)}$. This characteristic may justify the signs of appendicitis described in the present case. Granulomatous inflammation of the appendix is rarely found and may be caused by a variety conditions, including systemic causes such as Crohn's disease and sarcoidosis, or infection by Mycobacterium tuberculosis, Yersinia, parasites and fungi ${ }^{(16-18)}$.

Appendicitis occurs mainly due to obstruction of the lumen by appendicoliths, calculi, infectious processes, tumors and lymphoid hyperplasia. Once the appendiceal obstruction occurs, the continued mucosal secretion probably leads to an increase in the intraluminal pressure, causing venous drainage collapse. Then, the ischemic lesion favors bacterial proliferation ${ }^{(19)}$. In the present case, the lymphoid involvement of the organ by the fungus, leading to the development of an ileocecal mass, was the probable cause of luminal obstruction.

Tomographic findings of acute appendicitis include parietal thickening with diameter $>6 \mathrm{~mm}$, luminal distension, parietal contrast enhancement and periappendiceal fat infiltration. Appendiceal perforation and development of an abscess may occur ${ }^{(20)}$. In patients with intestinal PCM, computed tomography may show marked ileocecal wall thickening, sometimes corresponding to a mass, in association with a conglomerate group of enlarged lymph $\operatorname{nodes}^{(21)}$.

\section{REFERENCES}

1. Monjardim RF, Costa DMC, Romano RFT, et al. Diagnosis of hepatic steatosis by contrast-enhanced abdominal computed tomography. Radiol Bras. 2013;46:134-8

2. Hollanda ES, Torres US, Gual F, et al. Spontaneous perforation of gallbladder with intrahepatic biloma formation: sonographic signs and correlation with computed tomography. Radiol Bras. 2013;46:320-2.

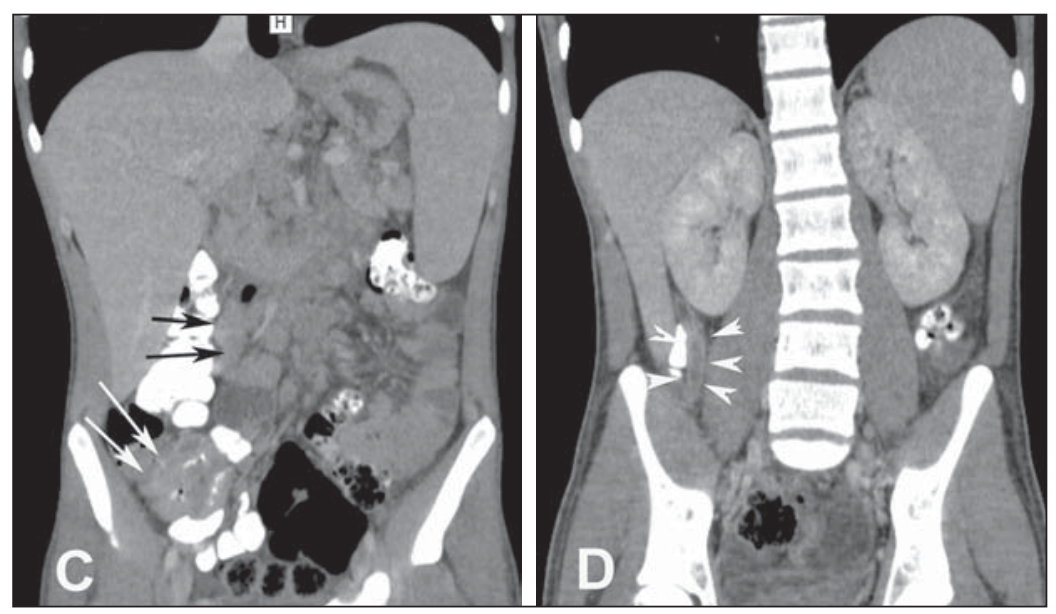

Figure 1. Abdominal computed tomography - axial image (A,B) demonstrates appendiceal thickening, luminal distension with parietal contrast enhancement and adjacent peritoneal fat infiltration (arrows). Also, mesenteric lymph nodes enlargement and ileocecal mass are observed (arrowheads). Coronal reconstructions (C,D) demonstrate ileocecal mass (white arrows) and mesenteric lymph nodes enlargement (black arrows) in association with appendiceal thickening with parietal contrast enhancement (arrowheads). 
3. Salvadori PS, Costa DMC, Romano RFT, et al. What is the real role of the equilibrium phase in abdominal computed tomography? Radiol Bras. $2013 ; 46: 65-70$

4. Costa DMC, Salvadori PS, Monjardim RF, et al. When the noncontrastenhanced phase is unnecessary in abdominal computed tomography scans? A retrospective analysis of 244 cases. Radiol Bras. 2013;46:197202.

5. Teixeira ACV, Torres US, Westin CEG, et al. Multidetector-row computed tomography in the preoperative diagnosis of intestinal complications caused by clinically unsuspected ingested dietary foreign bodies: a case series emphasizing the use of volume rendering techniques. Radiol Bras. 2013;46:346-50.

6. Kierszenbaum ML, von Atzingen AC, Tiferes DA, et al. Colonografia por tomografia computadorizada na visão do médico encaminhador: qual o seu valor segundo a visão de especialistas? Radiol Bras. 2014;47:13540 .

7. Francisco FAF, Araújo ALE, Oliveira Neto JA, et al. Contraste hepatobiliar: diagnóstico diferencial das lesões hepáticas focais, armadilhas e outras indicações. Radiol Bras. 2014;47:301-9.

8. Terceiro MG, Faria IM, Alfenas R, et al. Hérnia de Amyand com apendicite perfurada. Radiol Bras. 2014;47(6):xi-xiii.

9. Cunha EFC, Rocha MS, Pereira FP, et al. Necrose pancreática delimitada e outros conceitos atuais na avaliação radiológica da pancreatite aguda. Radiol Bras. 2014;47:165-75.

10. Kadow JS, Fingerhut CJP, Fernandes VB, et al. Peritonite encapsulante: tomografia computadorizada e correlação cirúrgica. Radiol Bras. 2014; 47:262-4.

11. Pedrassa BC, Rocha EL, Kierszenbaum ML, et al. Tumores hepáticos incomuns: ensaio iconográfico - Parte 1. Radiol Bras. 2014;47:3106.

12. Pedrassa BC, Rocha EL, Kierszenbaum ML, et al. Tumores hepáticos incomuns: ensaio iconográfico - Parte 2. Radiol Bras. 2014;47:3749.

13. Shinakai-Yasuda MA, Telles Filho FQ, Mendes RP, et al. Consenso em paracoccidioidomicose. Rev Soc Bras Med Trop. 2006;39:297-310.

14. Campos EP, Padovani CR, Cataneo AMJ. Paracoccidioidomicose: estudo radiológico e pulmonar de 58 casos. Rev Inst Med Trop São Paulo. 1991; $33: 267-76$.

15. Costa MAB, Carvalho TN, Araújo Júnior CR, et al. Manifestações extrapulmonares da paracoccidioidomicose. Radiol Bras. 2005;38:45-52.

16. Tucker ON, Healy V, Jeffers M, et al. Granulomatous appendicitis. Surgeon. 2003; 1:286-9.

17. AbdullGaffar B. Granulomatous diseases and granulomas of the appendix. Int J Surg Pathol. 2010;18:14-20.

18. Bronner MP. Granulomatous appendicitis and the appendix in idiopathic inflammatory bowel disease. Semin Diagn Pathol. 2004;21:98-107.

19. Carr NJ. The pathology of acute appendicitis. Ann Diagn Pathol. 2000; $4: 46-58$.

20. Chojniak R, Vieira RAC, Lopes A, et al. Intestinal paracoccidioidomycosis simulating colon cancer. Rev Soc Bras Med Trop. 2000;33:309-12.

21. Birnbaum BA, Wilson SR. Appendicitis at the millennium. Radiology. 2000;215:337-48.

Priscila Gava ${ }^{1}$, Alessandro Severo Alves de Melo ${ }^{1}$, Edson Marchiori $^{1}$, Márcia Henriques de Magalhães Costa $^{1}$, Eric Pereira $^{1}$, Raissa Dantas Batista Rangel ${ }^{1}$

1. Hospital Universitário Antônio Pedro (HUAP), Rio de Janeiro, RJ, Brazil. Mailing Address: Dra. Priscila Gava. Rua Vítor Meireles, 198 Condomínio Green Country, Mata Paca. Niterói, RJ, Brazil, 24322 110. E-mail: pris_gava@hotmail.com.

http://dx.doi.org/10.1590/0100-3984.2014.0035

\section{Biliary colon: an unusual case of intestinal obstruction}

Cólon biliar: um caso incomum de obstrução intestinal

\section{Dear Editor,}

A female, 80-year-old, diabetic, hypertensive and obese patient reported sudden onset of colicky pain in the hypogastrium for two days. Also, there was association with nausea, and the patient was unable to eliminate feces and pass gas, besides presenting with abdominal distension. Physical examination demonstrated increased abdominal volume, pain to deep palpation of the hypogastrium, abdominal tympanism to percussion and signs of mild dehydration. The clinical hypothesis of obstructive syndrome was raised.

Abdominal radiographic and sonographic images acquired in other service were not conclusive as regards the cause of the condition. Anteroposterior radiography in orthostasis and horizontal dorsal decubitus position demonstrated the presence of obstruc- tion with predominantly gaseous distension of small bowel loops and part of the large bowel, with no signs of pneumoperitoneum. Ultrasonography demonstrated gaseous distension with no signs of free fluid at the moment of the study. With such studies indicating low obstruction with no defined cause, one has opted for performing abdominal computed tomography (CT) in order to clarify the diagnosis and define the therapeutic approach.

Due to the clinical suspicion of neoplastic obstruction, the patient was referred to the authors' institution. With the CT study, the diagnosis could be established, and the several image reconstruction techniques - multiplanar, curve and $3 \mathrm{D}$ reconstruction - were utilized so as the findings could be presented to the requesting physician in a more easily understandable way.

CT demonstrated the fistulous tract communicating the gallbladder lumen with the lumen of the transverse colon and the presence of a residual calculus in the gallbladder (Figure 1A). Curve reconstruction of the rectal and sigmoid colon region demonstrated an impacted calculus obstructing the sigmoid colon and
Figure 1. A: Axial CT image demonstrating the presence of a calculus in the gallbladder (arrow) and fistulous tract communicating the gallbladder with the large bowel (asterisk). B: Curve reconstruction of CT image demonstrating impacted biliary calculus in the sigmoid colon (arrow) and bowel distension upstream (asterisk).
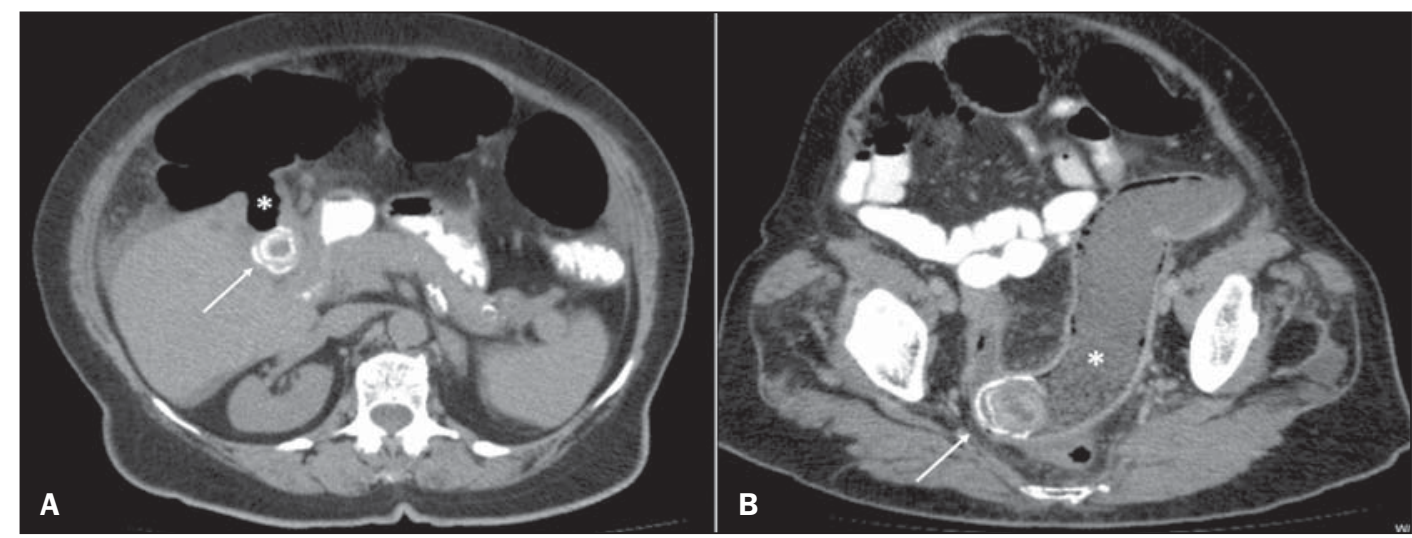